\title{
Classification and Intensity Assessment of Korean Emotion Expressing Idioms for Human Emotion Recognition
}

\author{
Ji-Eun Park ${ }^{1}$, Sunju Sohn ${ }^{2}$, Jin-Hun Sohn ${ }^{1}$ \\ ${ }^{1}$ Department Psychology/Brain Research Institute, Chungam National University, Daejeon, 305-764 \\ ${ }^{2}$ Department of Social Welfare, Cheongju University, Cheongju, 360-764
}

\begin{abstract}
Objective: The aim of the study was to develop a most widely used Korean dictionary of emotion expressing idioms. This is anticipated to assist the development of software technology that recognizes and responds to verbally expressed human emotions. Method: Through rigorous and strategic classification processes, idiomatic expressions included in this dictionary have been rated in terms of nine different emotions (i.e., happiness, sadness, fear, anger, surprise, disgust, interest, boredom, and pain) for meaning and intensity associated with each expression. Result: The Korean dictionary of emotion expression idioms included 427 expressions, with approximately two thirds classified as 'happiness'(n=96), 'sadness'( $\mathrm{n}=96)$, and 'anger'( $n=90)$ emotions. Conclusion: The significance of this study primarily rests in the development of a practical language tool that contains Korean idiomatic expressions of emotions, provision of information on meaning and strength, and identification of idioms connoting two or more emotions. Application: Study findings can be utilized in emotion recognition research, particularly in identifying primary and secondary emotions as well as understanding intensity associated with various idioms used in emotion expressions. In clinical settings, information provided from this research may also enhance helping professionals' competence in verbally communicating patients' emotional needs.
\end{abstract}

Keywords: Korean emotion idiom, Emotion, Emotion recognition, Emotion classification

\section{Introduction}

음성의 특징이나 언어 표현에 기반하여 인간의 감정을 인 식하는 기술은 Human-Computer Interface $(\mathrm{HCI})$ 분야에 서 활발히 연구되고 있다(Moataz et al., 2011). 본 연구팀 에서도 인간이 감정을 느낄 때 발생되는 여러가지 생체 신 호 및 얼굴 표정과 음성을 이용하여 인간의 감정을 읽어내 려는 연구를 진행하고 있다. 그 중에서도 언어는 인간이 경 험하는 다양한 감정을 보다 정교하게 표현할 수 있는 가장
발달된 감정 표현 수단이기 때문에 $(\mathrm{Kim}, 2001)$ 언어적 표 현이 전달하는 감정을 인식하는 작업은 기계가 인간의 감정 을 읽어내기 위해 반드시 필요하다. 예를 들어 환자를 돌보 는 도우미 로봇이 환자로부터 '차라리 죽고 싶어'라는 말을 들었을 때, 인간이 죽을 수 있도록 도와주는 행동을 한다면 이는 심각한 오류를 범하는 것이다. 이는 로봇이 인간의 언 어 표현에 포함된 감정을 잘못 인식했거나 판단했기 때문이 다. 로봇에게 언어 표현에 포함된 감정 반응을 정확히 파악하 는 능력을 부여하기 위해서는, 인간의 감정 표현 언어에 관 한 풍부하고 정교한 데이터베이스를 갖는 것이 필수적이다.

Corresponding Author: Jin-Hun Sohn. Department Psychology/Brain Research Institute, Chungam National University, Daejeon, $305-764$. Phone: +82-42-821-6369, E-mail: jhsohn@cnu.ac.kr Copyright@2012 by Ergonomics Society of Korea(pISSN:1229-1684 eISSN:2093-8462). All right reserved.

(c) This is an open-access article distributed under the terms of the Creative Commons Attribution Non-Commercial License(http://creativecommons.org/licenses/by-nc/3.0/), which permits unrestricted non-commercial use, distribution, and reproduction in any medium, provided the original work is properly cited. http://www.esk.or.kr 
본 연구는 인간이 감정을 표현할 때 사용하는 언어 표현 중에서 특히 관용어 표현을 분류하고 정리하여 감정 별 관용 어 분류 사전을 작성하는데 그 목적이 있다.

관용어란 두 단어 이상으로 구성되어 있지만, 하나의 의미 단위를 이루어, 하나의 어휘소로서 기능하는 언어 단위를 말 한다(Kwon, 2009). 즉 구조적으로는 두 단어 이상이 결합 되었지만 의미적으로는 단일한 의미를 가져 개별 단어의 의 미적 결합이 아닌 제3의 의미를 갖게 된다(Kim, 2001). 예 를 들어 '귀가 얇다'라는 관용어는 '귀'와 '얇다'라는 두 개의 단어가 결합하여, 실제로 귀의 두께가 얇다는 의미를 표현하 는 것이 아니라 '남의 말을 쉽게 받아들인다'(Naver Korean Dictionary)는 새로운 의미를 형성하게 되는 것이다.

본 연구에서는 관용어 중에서 감정 표현 관용어만을 평가 대상으로 하였다. 감정 표현 관용어란 감정의 경험, 야기, 표 출과정을 표현하는 관용어를 말한다(Chang, 1994).

연구 대상을 감정 표현 관용어로 정한 이유는 첫째, 한국 어의 이해에 관용어가 차지하는 비중이 크기 때문이고(Lee, 1997 둘째, 언어를 이용한 감정 인식 연구에서 개별 단어 들의 감정 분석만으로는 화자의 감정을 정확히 인식할 수 없기 때문이다.

관용어가 표현하는 감정은 개별 단어로 표현하는 감정을 뛰어넘어 전혀 새로운 감정을 표현하게 된다. 예를 들면 '입 이 찢어지다'가 '입'과 '찢어지다'가 각각 표현하는 개별 감정 의 결합이 아닌 '매우 기쁨'의 감정을 표현하는 것이다. 뿐만 아니라 동일한 '찢어지다'라는 단어를 사용하더라도 '가슴이 찢어지다'가 표현하는 감정은 '입이 찢어지다'와는 전혀 다른 감정을 표현하고 있다.

이러한 이유에서 기계가 인간의 언어를 통해 감정 인식을 정확하게 하기 위해서는 감정 별로 세분화되고 정교화된 관 용어 사전이 필요하다.

한국어 감정 표현 관용어에 관해 본격적으로 연구가 시작 된 것은 220 개의 관용어를 정서 야기, 정서 경험, 정서 표출 등으로 분류한 Chang(1994)을 들 수 있다. 그 이후 Kim (2001)은 기쁨, 슬픔, 분노, 두려움, 사랑, 미움으로 516 개 의 관용어를 분류하였고 Kwon(2005)은 감정의 범주를 긍 정적 감정과 부정적 감정으로 나누어 272 개를 분류하였다.

본 연구에서는 427 개의 관용어를 기쁨, 슬픔, 분노, 공포, 놀람, 혐오, 흥미, 지루함, 아픔의 9 가지 감정 범주로 분류 하였고, 각 감정 범주 별 관용어가 가지는 감정의 강도도 평 가하였다. 본 연구와 기존 연구의 차이점은 첫째, 자료 수집 방법의 차이이다. 기존 연구는 문헌에서 수집한 자료를 기반 으로 하였고, 본 연구는 문헌 자료뿐 아니라 일상 생활에서 사용하는 구어 자료를 포함하고 있다. 요즘 대학생들이 평소 에 감정을 표현할 때 사용하는 관용어를 조사하여 자료에 포함시켰다. 둘째, 감정 분류 방법의 차이이다. 기존 연구들
은 관용어의 의미와 표현법에 근거한 언어학적인 분류인데 반해, 본 연구는 대학생들이 그 관용어를 어떻게 느끼고 사 용하는지 실제적인 감정 표현을 평가하도록 하여 수행된 심 리학적 연구이다. 따라서 로봇이 인간의 언어 표현을 이용하 여 감정 인식을 수행할 때, 실용적인 데이터베이스를 제공할 수 있을 것이다. 그러므로 본 연구는 인간의 일상 대화 장면 에서 사용되는 실제적인 관용 표현에 내포된 감정을 분류함 으로써 그것을 통해 인간의 감정을 파악할 수 있는 중요한 정보를 제공하는 자료를 마련했다는 점에서 그 가치를 둘 수 있겠다.

\section{Method}

\subsection{Idioms collection}

본 연구에서는 감정 표현 관용어에 관한 선행 논문들을 참 고하여 관용어들을 1차로 수집하였다. Kwon(2009)의 한 국 관용어의 의미적 연구에서 신체와 관련된 관용어 160 개, Kwon(2005)의 한국 관용어의 활용에서 긍정적 감정 관용 표현 95 개와 부정적 감정 관용 표현 177 개, 5 개 대학 한 국어 교재 별 관용 표현 현황 정리 목록에서 323개(Kwon, 2005), $\mathrm{Kim}$ (2000)의 긍 · 부정감정을 나타내는 관용 표현 목록에서 81개를 수집하였다. 2차로 일상 생활에서 많이 사 용하는 구어체 표현 수집을 위해 국문학 전공 연구자들 3 인 (박사)에게 평소에 일상 생활에서 많이 사용하는 감정 표현 관용어를 수집하도록 하여 중복을 제거한 후 61 개를 수집하 였다. 1,2 차 수집 자료를 통합한 후 최종 정리한 결과 633 개의 관용어 리스트를 얻을 수 있었다.

\subsection{Questionnaire(Rating Survey)}

평가 설문지의 작성은 한 페이지당 33 개씩 관용어를 넣고, '당신은 어떤 감정을 느낄 때 다음 표현을 쓰는지 11 개의 감정 범주 보기 중에서 고르시오'라고 지시하였다. 만일 제 시된 관용어가 '기쁨', '슬픔', '공포', '분노', '혐오', '놀람', '흥미', '지루함', '통증', '중성'의 10 개 범주 이외에 해당할 경우 '기 타' 범주에 그 감정 종류를 직접 쓰도록 하였다. 이 중 '중 성'은 제시된 관용어가 감정 표현과 관련이 없는 경우를 의 미한다.

수집된 목록에 문어체 표현들이 많이 포함되어 있음을 감 안하여 관용어의 의미를 모르거나 잘 사용하지 않는 관용어 인 경우에는 문항 번호에 별도로 표시를 하도록 하여 관용어 의미에 대한 이해도를 결과 분석에 반영하였다.

무성의한 응답을 판단하기 위해 15 개의 중복 문항을 삽입 
하여 일관된 응답이 나오는지 확인하였다. 중복 문항을 포함 하여 총 648 문항을 순서효과를 상쇄하기 위하여 제시순서를 무작위로 섞어 3 세트의 관용어 감정 평가용 설문지를 작성 하였다.

\subsection{Emotion assessment}

관용어 감정 평가용 설문지를 이용하여 각 관용어의 '감 정 범주', '감정의 강도'와 '이해도'를 동시에 평가하였다. 범 주 분류는 개수에 제한 없이 복수개의 범주를 선택할 수 있 고, 감정의 강도는 '각 관용어가 해당 감정을 얼마나 강하게 표현하는지'를 10점 만점으로 평가하였다.

설문 응답에 소요되는 시간을 계산하기 위해 3 명의 대학 생에게 예비 검사를 실시해 본 결과 600 개 이상의 관용어에 대한 '감정 범주'와 '감정 강도'를 평가하는 일은 3 시간 정도 소요되는 인지적 부담이 많은 작업이었다. 따라서 본 평가에 서는 평가 설문지 분량을 반으로 나눈 뒤 모든 참가자에게 이틀에 걸쳐 평가에 참여하도록 하였다. 충남대학교 게시판 을 통해 80명의 남녀 대학생 참가자를 모집하였고 참가자 본인들이 원하는 시간을 선택하여 강당에 모여 1시간 1시 간 30 여분 동안 설문지 절반을 평가하였고 그 다음날 이 과 정을 한번 더 실시하여 한 세트의 설문 평가를 완성하였다. 관용어 감정 평가에 대한 주의와 동기 수준을 고취하고, 성 실한 응답을 유도하기 위하여 참여자들에게는 15,000 원 상 당의 상품권을 지급하였다.

\section{Results}

\subsection{Classification of idiomatic emotion expressions}

결과를 분석하기 앞서 참가자의 $10 \%$ 이상이 제시된 관용 어의 의미를 이해하지 못하거나 평소에 사용하지 않는다고 표시한 문항들은 결과 분석에서 제외하였다. '오금을 떼어 놓을 수 없다', '귀를 적시다' 등을 포함한 54 개의 문항이 이 에 해당되어 결과 분석에서 제외되었다.

중복으로 넣었던 15 개의 더미 문항에 대한 평가도 범주 일치 여부를 확인한 후 분석에서 제외하였다. 즉, '의미 모름 '과 더미 문항을 제외한 나머지 관용어의 평가 결과를 분석
하였다. 각 관용어가 어느 감정 범주에 속하게 되는지를 결 정하는 가장 기본적인 원칙은 11 개의 감정 범주 중 가장 높 은 빈도로 선택된 감정 범주를 그 관용어의 대표 감정으로 결정하는 것이다. 따라서 빈도수를 총 11 개 범주에 대한 백 분율로 환산하여 빈도 백분율 순으로 1 순위부터 11 순위까 지 정렬했을 때 그 1 순위에 해당되는 범주를 그 관용어의 1 차 범주로 분류하였다. 예를 들어 '간이 서늘하다'의 경우 빈도 백분율의 정렬 결과가 공포 $89.94 \%$ 로 1순위이고 놀람 이 2순위로 $9.7 \%$, 혐오 $0.18 \%$, 그 외 나머지 감정들 $0.1 \%$ 미만들로 나열될 수 있었다. 따라서 '간이 서늘하다'는 1 순 위 범주인 공포를 표현하는 관용어로 분류한다.

그러나 만일 $51 \%$ 와 $49 \%$ 혹은 $40 \%, 35 \%, 30 \%$ 처럼 1순 위와 2순위 혹은 3순위 범주간의 비율이 근소한 차이로 범 주 순위가 나열될 때는 차 상위 빈도 값의 $70 \%$ 이상에 해 당하는 범주까지 2 차, 3 차 범주로 채택하여 다중 감정을 표 현하는 관용어로 분류하였다. 예를 들면, '하늘이 캄캄하다' 는 슬픔, 공포, 기타 범주가 각각 $46.93 \%, 34.48 \%, 14.07 \%$ 로 2순위 값(34.48\%)이 1순위 값(46.93\%)의 $70 \%$ 선을 넘는다. 그러나 3순위 값(14.07\%)는 2순위 값(34.48\%)의 $70 \%$ 선을 넘지 못하므로 '하늘이 캄캄하다'는 슬픔과 공포를 각각 1 차, 2 차 범주로 채택하여 2 가지의 감정 표현에 모두 사용되는 다중 감정 관용어로 분류하였다. 다중 감정 관용어 의 목록의 일부를 Appendix 2에 수록하였다.

\subsection{Results on emotion classification and intensity assessment of idiomatic emotion expressions}

각 1 차 감정 범주에 해당하는 감정 표현 관용어의 개수와 강도 평균은 Table 1 과 같다. 강도 평균은 각 범주에 해당하 는 관용어들의 강도 평정치의 평균으로, 공포에 해당하는 39 개 관용어들은 공포를 평균 7.79 정도 느낄 때 사용된다 고 볼 수 있다. 중성과 기타로 분류된 관용어는 평균 산출과 정에서 제외하였다. 그 이유는 중성으로 분류된 관용어는 감 정 표현과 관련된 것이 아니고, 기타 감정으로 분류된 관용 어는 여러 가지의 감정 결과가 섞여있어 강도 평균을 내는 것은 의미가 없기 때문이다.

분석 결과를 요약해 보면, 감정 표현 관용어 중 '기쁨'과 '슬픔'을 표현하는 관용어가 96개로 가장 많았으며, 다음으 로 '분노'90개 순 이었다(Table 1).

Table 1. Results on emotion classification and intensity assessment of idiomatic emotion expressions

\begin{tabular}{c|c|c|c|c|c|c|c|c|c|c|c}
\hline & 공포 & 기쁨 & 놀람 & 분노 & 슬픔 & 지루함 & 통증 & 혐오 & 흥미 & 중성 & 기타 \\
\hline 관용어수(개) & 39 & 96 & 21 & 90 & 96 & 5 & 23 & 17 & 40 & 120 & 32 \\
\hline 강도평균(점) & 7.79 & 7.76 & 8.16 & 7.58 & 7.54 & 8.39 & 7.05 & 6.93 & 7.58 & & \\
\hline
\end{tabular}


각 범주 별 상세한 평가 결과의 목록은 Appendix 1에 수 록하였다.

\section{Conclusion and Discussion}

본 연구는 감정 표현 관용어를 9 가지의 감정 범주로 분류 하고 각각의 관용어가 표현하는 감정의 강도를 평가하였다.

감정 범주 평가 결과, 기쁨, 슬픔, 분노 감정을 표현하는 관용어 표현들이 전체의 $66 \%$ 이상을 차지하고, 그 외 공포 와 흥미가 $10 \%$ 씩, 놀람, 통증, 혐오가 $5 \%$ 씩으로 그 뒤를 차지한다. 각 감정 별 관용어의 사용빈도 분포가 가지는 사 회 문화적 의미는 본 연구의 의도나 목적에 부합하지 않으 므로 논의에서 제외하지만 추후 분석을 통해 그 의미를 찾 아보는 것도 의의가 있을 것이다. 인간의 감정을 탐색하거 나 인식하는 대부분의 연구들이 기본 감정 규명에만 주력 (Zeng et al., 2009)하고 있음을 볼 때 이 연구의 결과에서 나타난 현상이 보편성도 있으리라 생각된다. 그러나 인간이 사회적 상황에서 경험하는 감정은 기본 감정보다 훨씬 다양 하므로 가능한 다양한 범주의 감정 분류 목록이 필요하다. 이러한 맥락에서 본 연구는 기본 감정 6 가지 이외에 감정 연구에서 많이 연구되고 있는 흥미와 지루함을 추가하였다. 그리고 일상 장면에서 활용될 경우를 고려하여 통증을 더 추 가하여 9 가지의 범주를 고려하였다. 따라서 본 연구 목록을 감정 인식에 활용한다면, 기본 감정 이외의 감정들도 인식할 수 있고 통증관련 응급 상황까지도 탐지 가능하며, 더불어 감정 경험의 강도까지 탐색할 수 있을 것이다.

본 연구는 이제까지 이루어진 언어 의미적인 연구와 달리 대학생들이 실생활에서 사용하는 언어 생활을 그대로 반영 한 심리 연구라는 점에서 그 의미가 있다. 연구 방법에서 기 술했듯이 본 연구에서는 기존에 국문학 혹은 언어학 분야에 서 연구된 한국어 관용어 목록에 실생활에서 사용하는 관용 어 목록을 추가하여 확장된 목록을 만들고 그것을 평가하였 다. 수집된 목록에는 문어체 표현들이 많이 포함되어 있음을 감안하여 평가 시에 제시된 문항의 관용어 의미를 모르거나 사용하지 않는 관용어를 표시하도록 하였다. 그 결과 응답자 중 한 명 이상 제시된 문항에서 관용어의 의미를 모르거나 사용하지 않는다고 표시한 문항이 전체의 $75 \%$ 에 달했다(즉, 평가 목록에 제시된 $25 \%$ 만이 모든 참가자들에게 익숙한 관 용어이다). 이는 수집된 관용어들에 문어체가 많이 포함되어 있으며, 이러한 문어체의 감정 표현 관용어들은 일상 생활에 서 자주 사용되지 않음을 의미한다. 이는 현재 대학생들의 일상 생활 감정 표현 언어와 우리말 관용어 표현에 익숙지 않은 양상을 반영한 것이라 할 수 있어 현대 청소년들의 감
정 표현 언어 연구에 기초 자료가 될 뿐 아니라 실용품 제작 에 유용한 자료로 활용될 것이라 생각된다.

본 연구의 한계점은 첫째, 설문 응답자의 수가 작다는 것 이다. 대학생 80 명을 대상으로 약 650 개의 관용어를 분류 한 결과 뚜렷한 범주 특성을 보이지 않는 관용어의 경우는 범주 분류가 분명하게 나누어 지지 않았다. 좀더 많은 수의 인원을 대상으로 추가적인 평가가 이루어진다면 그러한 관 용어들도 유의미한 분류 결과를 얻을 수 있을 것으로 생각 된다. 그러나 무성의한 응답을 피하기 위하여 추가했던 중복 문항쌍은 모두 같은 범주로 분류됨을 확인하여 응답의 신뢰 성을 확인할 수 있었다.

둘째는 관용어의 이해도를 평가하기 위하여 의미를 모르 거나 사용하지 않는 관용어를 표시하도록 했으나 이 결과를 보면 대부분의 중성 관용어와 관련됨을 알 수 있었다. 즉 감 정 표현이 아닌 관용어를 중성 범주로 분류하고 다시 '사용 안 함으로 중복 표시하는 경향이 있던 것으로 보여진다. 그 러나 결과적으로는 중성 범주의 관용어는 감정 표현 관용어 범주 분류에 들지 않으므로 감정 범주 분류 결과에는 영향을 크게 미치지 않았다고 생각된다.

이러한 연구의 한계점을 가지고 있긴 하지만 본 연구에서 작성된 감정 표현 관용어 목록은 구어체들까지도 통합하여 각 관용어들이 표현하는 감정의 심리적 범주와 강도를 평가 하였고 하나의 관용어가 복수개의 감정을 표현하는 비율을 반영하여 다중 감정 범주로 분류함으로써 실용성을 반영하 였다.

$\mathrm{HCI}$ 분야에서는 상대방이 표현하는 언어에서 감정을 정확 하게 인식하기 위한 연구들도 매우 활발하게 진행되고 있다 (Lee, 2005; Pantic, 2005; Scherer, 2003). 그 결과, 로봇 튜터, 로봇 카운셀러, 실버 도우미 로봇 등 인간과 직접 상호 작용하는 로봇들이 속속 등장하고 있다. 예를 들어, 상담 치 료 장면에서도 내담자의 감정 상태를 파악하고 공감하는 것 이 매우 중요한데(Wynn and Wynn, 2006) 로봇 카운셀러 가 내담자의 감정을 파악하려면 언어의 감정 별 분류 목록 은 필수적이다. 뿐만 아니라 감성 공학, 감성 마케팅, 감성 교육 등 여러 분야에서 인간의 감정을 인식하고 측정하기 위 해 여러 가지 방법을 시도하고 있다. 그러나 이러한 연구들 이 모두 미국, 유럽 등에서 선도되고 있어 모두 잘 정리된 영어 데이터베이스들을 이용하고 있어 우리말을 이용한 연 구에 적용하기는 어려운 실정이다. 우리나라의 언어 감정 인 식 기술이 발전하기 위해서는 잘 정리된 우리말 감정 표현 자료들이 반드시 필요하다. 따라서 본 연구 결과는 이러한 면에서 활용가치를 찾을 수 있다.

결론적으로 이러한 감정 표현에 관련된 관용어 자료는 심 리학이나 언어학에서뿐만 아니라 인간의 감정을 인식하는 $\mathrm{HCI}$ 분야를 비롯한 공학 및 산업 분야에까지 다양하게 활용 
될 수 있다는 점에서 그 가치가 높다고 하겠다.

\section{Acknowledgements}

This research was supported by the Converging Research Center Program funded by the Ministry of Education, Science and Technology (Grant\# 2012K001339).

\section{References}

Chang, S. K. and Chang, K. H., Korean idioms - About emotion, Journal of Korean Studies, 25, 295-318, 1994

Kim, H. S., Statistical study of idiomatic phrases in current Korean, Master. Dissertation, Yonsei University, 2000.

Kim, H. S., A study on Korean emotional idioms, Ph.D. dissertation, Inha University. 2001.

Kwon, K. I., A Study on the semantic characteristics of Korean emotion idioms, Journal of Grammar Education, 11, 119-140, 2009.

Kwon, S. Y., Application methods about Korean idiomatic expression, Master. Dissertation, Hanyang University, 2005.

Lee, C. M. and Narayanan, S. S., Toward detecting emotions in spoken dialogs. IEEE Trans. Speech and Audio Process, 13(2), 293-303, 2005.

Lee, K. D., Idiom, metaphor, and metonymy, Discourse and Cognition, 4(1), 61-87, 1997.

Moataz, E. A., Mohamed, S. K. and Fakhri, K., Survey on speech emotion recognition: Features, classification schemes and databases, Pattern Recognition, 44, 572-587, 2011.

Naver Korean Dictionary, http://krdic.naver.com

Pantic, M., Sebe, N., Cohn, J. F. and Huang, T., "Affective multimodal human-computer interaction", Proc. 13th ACM Int'l Conf. Multimedia (Multimedia '05), 669-676, 2005.

Scherer, K. R., Vocal communication of emotion: A review of research paradigms. Speech Communication, 40, 227-256, 2003.

Wynn, R. and Wynn, M., Empathy as an interactionally achieved phenomenon in psychotherapy: Characteristics of some conversational resources, Journal of Pragmatics, 38(9), 1385-1397, 2006.

Zeng, Z., Pantic, M., Roisman, G. I. and Huang, T. S., A Survey of Affect recognition methods: Audio, visual, and spontaneous expressions, IEEE Trans. Pattern analysis and Machine Intelligence, 31(1), 39-58, 2009.
[Appendix 1] 각 범주 별 관용어 목록

\begin{tabular}{|c|c|c|c|}
\hline $\begin{array}{l}\text { 감정 } \\
\text { 범주 }\end{array}$ & 관용어 & $\begin{array}{c}\text { 감정강도 } \\
\text { 평균 }\end{array}$ & $\begin{array}{l}\text { 감정강도 } \\
\text { 표준편차 }\end{array}$ \\
\hline 공포 & 등골이 오싹하다(해지다) & 9.14 & 1.73 \\
\hline 공포 & 얼굴이 파맇게 질리다 & 9.03 & 1.56 \\
\hline 공포 & 얼굴이 하얗게 질리다 & 9.00 & 1.66 \\
\hline 공포 & 등골이 서늘하다(해지다) & 8.82 & 1.87 \\
\hline 공포 & 얼굴이 파래지다 & 8.79 & 1.70 \\
\hline 공포 & 등(골)에 식은땀이 흐른다 & 8.67 & 1.79 \\
\hline 공포 & 얼굴이 새파랗게 되다 & 8.63 & 1.91 \\
\hline 공포 & 얼굴이 하애지다 & 8.60 & 1.76 \\
\hline 공포 & 간(담)이 서늘하다(해지다) & 8.44 & 1.82 \\
\hline 공포 & 소름이 끼치다 & 8.39 & 1.87 \\
\hline 공포 & 가슴이 섬뜩섬뜩하다 & 8.36 & 2.18 \\
\hline 공포 & 머리카락이 곤두서다 & 8.32 & 1.76 \\
\hline 공포 & 소름이 돋다 & 8.23 & 1.86 \\
\hline 공포 & 머리가 쭈뼛해지다 & 8.14 & 1.90 \\
\hline 공포 & 다리가 후들거리다 & 8.14 & 1.79 \\
\hline 공포 & 오금이 저리다 & 8.10 & 1.80 \\
\hline 공포 & 간이 콩알만 하다(해지다) & 8.00 & 2.26 \\
\hline 공포 & 살이 떨리다 & 8.00 & 1.95 \\
\hline 공포 & 겁이 나다 & 7.87 & 2.07 \\
\hline 공포 & 간이 오그라들다 & 7.85 & 2.08 \\
\hline 공포 & 가슴이 방망이질 치다 & 7.82 & 2.28 \\
\hline 공포 & 간이 떨리다 & 7.76 & 2.33 \\
\hline 공포 & 몸을 떨다 & 7.69 & 2.04 \\
\hline 공포 & 살을 떨다 & 7.66 & 1.94 \\
\hline 공포 & 가슴이 서늘하다(해지다) & 7.65 & 2.42 \\
\hline 공포 & 닭살이 돋다 & 7.48 & 2.08 \\
\hline 공포 & 눈앞이 아찔하다 & 7.41 & 1.97 \\
\hline 공포 & 뒷걸음을 치다 & 7.32 & 2.35 \\
\hline 공포 & 피를 말리다 & 7.29 & 2.15 \\
\hline 공포 & 손에 땀이 나다 & 7.22 & 2.14 \\
\hline 공포 & 간이 조마조마하다 & 7.00 & 2.23 \\
\hline 공포 & 꽁무니를 빼다 & 7.00 & 2.36 \\
\hline 공포 & 찍(끽)소리도 못하다 & 6.92 & 2.48 \\
\hline 공포 & 숨도 크게 못 쉬다 & 6.82 & 2.21 \\
\hline 공포 & 구석으로 내몰리다 & 6.71 & 2.62 \\
\hline 공포 & (눈)앞이 캄캄(깜깜)하다 & 6.60 & 2.68 \\
\hline 공포 & 목을 움츠리다 & 6.47 & 2.18 \\
\hline 공포 & 숨(을)죽이다 & 6.34 & 2.70 \\
\hline 공포 & 마음을 졸이다 & 6.00 & 2.70 \\
\hline
\end{tabular}


[Appendix 1] 각 범주 별 관용어 목록 (Continued)

\begin{tabular}{|c|c|c|c|}
\hline $\begin{array}{l}\text { 감정 } \\
\text { 범주 }\end{array}$ & 관용어 & $\begin{array}{l}\text { 감정강도 } \\
\text { 평균 }\end{array}$ & $\begin{array}{l}\text { 감정강도 } \\
\text { 표준편차 }\end{array}$ \\
\hline 기쁨 & 날아갈 듯하다(것 같다) & 9.52 & 1.13 \\
\hline 기쁨 & 어깨춤이 (절로) 나다(나오다) & 9.46 & 1.23 \\
\hline 기쁨 & 입이 함박만하다 & 9.33 & 1.56 \\
\hline 기쁨 & 신이 나다 & 9.23 & 1.06 \\
\hline 기쁨 & 입이 찢어지다 & 9.21 & 1.48 \\
\hline 기쁨 & 어깨춤을 추다 & 9.15 & 1.66 \\
\hline 기쁨 & 신명이 나다 & 9.03 & 1.45 \\
\hline 기쁨 & 콧노래를 부르다 & 8.82 & 1.69 \\
\hline 기쁨 & 신바람이 나다 & 8.79 & 1.76 \\
\hline 기쁨 & 가슴이 벅차오르다(벅차다) & 8.78 & 1.83 \\
\hline 기쁨 & 배꼽이 빠지다 & 8.74 & 1.80 \\
\hline 기쁨 & 콧노래가 나오다 & 8.73 & 1.61 \\
\hline 기쁨 & 살 맛 나다 & 8.71 & 1.47 \\
\hline 기쁨 & 배꼽을 잡다(빼다) & 8.71 & 1.55 \\
\hline 기쁨 & 십 년 묵은 체증이 내려가다 & 8.69 & 1.84 \\
\hline 기쁨 & 배꼽을 쥐다 & 8.68 & 1.63 \\
\hline 기쁨 & 배꼽이 달아나다 & 8.64 & 1.71 \\
\hline 기쁨 & 등 따습고 배부르다 & 8.59 & 1.81 \\
\hline 기쁨 & 깨가 쏟아지다 & 8.57 & 1.71 \\
\hline 기쁨 & 기분이 들뜨다 & 8.54 & 1.93 \\
\hline 기쁨 & 가슴이 뿌듯하다 & 8.47 & 1.70 \\
\hline 기쁨 & 가슴이 부풀다 & 8.45 & 1.84 \\
\hline 기쁨 & 한 턱 내다 & 8.44 & 1.67 \\
\hline 기쁨 & 발걸음이 가볍다 & 8.44 & 1.88 \\
\hline 기쁨 & 가슴이 시원하다 & 8.38 & 1.97 \\
\hline 기쁨 & 속 시원하다 & 8.38 & 1.82 \\
\hline 기쁨 & 앓던 이가 빠지다 & 8.35 & 1.80 \\
\hline 기쁨 & 마음이 들뜨다 & 8.29 & 1.52 \\
\hline 기쁨 & 발 뻗고 자다 & 8.28 & 1.60 \\
\hline 기쁨 & 가슴이 후련하다 & 8.27 & 1.93 \\
\hline 기쁨 & 한잔 사다 & 8.22 & 1.85 \\
\hline 기쁨 & 주머니가 넉넉하다 & 8.20 & 1.74 \\
\hline 기쁨 & 수입이 짭짤하다 & 8.18 & 2.14 \\
\hline 기쁨 & 밥을 먹지 않아도 배가 부르다 & 8.18 & 2.07 \\
\hline 기쁨 & 이름을 날리다 & 8.15 & 2.16 \\
\hline 기쁨 & 빛을 보다 & 8.14 & 1.84 \\
\hline 기쁨 & 휘파람을 불다 & 8.12 & 1.83 \\
\hline 기쁨 & 가슴이 두근거리다 & 8.10 & 1.86 \\
\hline 기쁨 & 눈에 넣어도 아프지 않다 & 8.10 & 2.12 \\
\hline
\end{tabular}

[Appendix 1] 각 범주 별 관용어 목록 (Continued)

\begin{tabular}{|c|c|c|c|}
\hline $\begin{array}{l}\text { 감정 } \\
\text { 범주 }\end{array}$ & 관용어 & $\begin{array}{c}\text { 감정강도 } \\
\text { 평균 }\end{array}$ & $\begin{array}{l}\text { 감정강도 } \\
\text { 표준편차 }\end{array}$ \\
\hline 기뽐 & 마음이 가볍다 & 8.09 & 1.98 \\
\hline 기쁨 & 금이야 옥이야 & 8.09 & 1.77 \\
\hline 기쁨 & 빛이 보이다 & 8.09 & 2.05 \\
\hline 기쁨 & 두 다리를 쭉 뻗다 & 8.05 & 2.10 \\
\hline 기쁨 & 박수를 보내다 & 8.04 & 1.96 \\
\hline 기뽐 & 손빽을 치다 & 8.00 & 2.12 \\
\hline 기쁨 & 마음이 시원하다 & 7.97 & 2.01 \\
\hline 기뽐 & 가슴이 뛰다 & 7.95 & 2.11 \\
\hline 기뽐 & 가슴이 설레다 & 7.87 & 1.95 \\
\hline 기쁨 & 어깨를 으쓱거리다 & 7.82 & 2.32 \\
\hline 기쁨 & 어깨가 가볍다 & 7.81 & 2.10 \\
\hline 기쁨 & 마음에 들다 & 7.80 & 2.20 \\
\hline 기뽐 & 어깨에 힘을 주다 & 7.73 & 2.45 \\
\hline 기쁨 & 심장이 뛰다 & 7.68 & 2.09 \\
\hline 기쁨 & 씻은 듯이 낫다 & 7.67 & 2.25 \\
\hline 기뽐 & 얼굴이 펴지다 & 7.60 & 2.22 \\
\hline 기뽐 & 손에 들어오다 & 7.56 & 2.39 \\
\hline 기쁨 & 속이 뚫리다 & 7.54 & 1.99 \\
\hline 기뽐 & 가슴이 훈훈해지다 & 7.53 & 2.00 \\
\hline 기뽐 & 가슴이 떨리다 & 7.50 & 2.23 \\
\hline 기뽐 & 다리를 뻗(펴)고 자다 & 7.43 & 2.25 \\
\hline 기뽐 & 속이 풀리다 & 7.39 & 2.31 \\
\hline 기뽐 & 마음이 통하다 & 7.37 & 1.98 \\
\hline 기뽐 & 몸이 가볍다 & 7.31 & 2.47 \\
\hline 기뽐 & 상다리가 부러지다 & 7.30 & 2.42 \\
\hline 기뽐 & 속이 트이다 & 7.30 & 2.39 \\
\hline 기쁨 & 가슴이 트이다 & 7.27 & 2.40 \\
\hline 기쁨 & 비행기(를) 태우다 & 7.27 & 2.51 \\
\hline 기뽐 & 죽이 맞다 & 7.21 & 2.30 \\
\hline 기쁨 & 머리가 가볍다 & 7.20 & 2.25 \\
\hline 기뽐 & 마음이 맞다 & 7.18 & 2.29 \\
\hline 기뽐 & 애지중지하다 & 7.17 & 2.18 \\
\hline 기쁨 & 기가 살다 & 7.15 & 2.48 \\
\hline 기뽐 & 손발이 맞다 & 7.15 & 2.12 \\
\hline 기쁨 & 가슴이 뜨거워지다(뜨겁다) & 7.14 & 2.61 \\
\hline 기쁨 & 눈이 맞다 & 7.12 & 2.32 \\
\hline 기쁨 & 마음을 주다 & 7.03 & 2.37 \\
\hline 기뽐 & 눈에 차다 & 6.97 & 2.11 \\
\hline 기뽐 & 가슴을 열다 & 6.93 & 2.32 \\
\hline
\end{tabular}


[Appendix 1] 각 범주 별 관용어 목록 (Continued)

\begin{tabular}{|c|c|c|c|}
\hline $\begin{array}{l}\text { 감정 } \\
\text { 범주 }\end{array}$ & 관용어 & $\begin{array}{l}\text { 감정강도 } \\
\text { 평균 }\end{array}$ & $\begin{array}{l}\text { 감정강도 } \\
\text { 표준편차 }\end{array}$ \\
\hline 기쁨 & 발을 뻗다 & 6.89 & 2.41 \\
\hline 기쁨 & 기를 펴다 & 6.88 & 2.57 \\
\hline 기쁨 & 벽을 허물다 & 6.85 & 2.46 \\
\hline 기쁨 & 입맛에 맞다 & 6.75 & 2.23 \\
\hline 기쁨 & 마음이 풀리다 & 6.74 & 2.39 \\
\hline 기쁨 & 허파에 바람들다 & 6.69 & 2.24 \\
\hline 기쁨 & 몸 둘바를 모르다 & 6.68 & 2.43 \\
\hline 기쁨 & 목에 힘이 들어가다 & 6.68 & 2.42 \\
\hline 기쁨 & 가슴을 펴다 & 6.67 & 2.46 \\
\hline 기쁨 & 숨통이 트이다 & 6.67 & 2.40 \\
\hline 기쁨 & 마음의 문을 열다 & 6.64 & 2.45 \\
\hline 기쁨 & 목에 힘을 주다 & 6.57 & 2.02 \\
\hline 기쁨 & 속을 터놓다 & 6.56 & 2.50 \\
\hline 기쁨 & 마음을 놓다 & 6.56 & 2.66 \\
\hline 기쁨 & 어깨를 펴다 & 6.51 & 2.70 \\
\hline 기쁨 & 마음이 놓이다 & 6.48 & 2.40 \\
\hline 기쁨 & 마음을 바치다 & 6.32 & 2.67 \\
\hline 기쁨 & 마음을 털어놓다 & 6.03 & 2.85 \\
\hline 기쁨 & 마음이 누그러지다 & 4.77 & 2.30 \\
\hline 놀람 & 애 떨어질 뻔하다 & 9.46 & 1.37 \\
\hline 놀람 & 입이 (딱)벌어지다 & 9.29 & 1.21 \\
\hline 놀람 & 눈이 (휘)둥그레지다 & 9.26 & 1.09 \\
\hline 놀람 & 간이 떨어지다 & 9.10 & 1.36 \\
\hline 놀람 & 입을 다물지 못하다 & 9.05 & 1.46 \\
\hline 놀람 & 가슴이 철렁 내려앉다 & 8.79 & 1.98 \\
\hline 놀람 & 꿈에도 모르다 & 8.55 & 1.87 \\
\hline 놀람 & 심장이 멎는 듯하다 & 8.52 & 1.84 \\
\hline 놀람 & 입을 벌리다 & 8.38 & 1.67 \\
\hline 놀람 & 말문이 막히다 & 8.26 & 1.65 \\
\hline 놀람 & 가슴이 덜컥(덜컹) 내려앉다 & 8.25 & 2.12 \\
\hline 놀람 & 눈이 번쩍 뜨이다 & 8.24 & 1.92 \\
\hline 놀람 & 어안이 벙벙하다 & 8.17 & 2.17 \\
\hline 놀람 & 귀를 의심하다 & 7.81 & 1.93 \\
\hline 놀람 & 가슴이 뜨끔하다 & 7.60 & 2.03 \\
\hline 놀람 & 속이 움찔하다 & 7.20 & 2.05 \\
\hline 놀람 & 입이 붙어 떨어지지 않다 & 6.90 & 2.07 \\
\hline 놀람 & 코앞에 닥치다 & 6.84 & 2.25 \\
\hline 놀람 & 속이 찔리다 & 6.40 & 2.74 \\
\hline 놀람 & 무릎을 치다 & 6.00 & 2.83 \\
\hline
\end{tabular}

[Appendix 1] 각 범주 별 관용어 목록 (Continued)

\begin{tabular}{|c|c|c|c|}
\hline 감정 & 관용어 & $\begin{array}{c}\text { 감정강도 } \\
\text { 평균 }\end{array}$ & $\begin{array}{l}\text { 감정강도 } \\
\text { 표준편차 }\end{array}$ \\
\hline 분노 & 피가 거꾸로 솟다 & 9.47 & 0.88 \\
\hline 분노 & 눈이 뒤집히다 & 9.29 & 1.30 \\
\hline 분노 & 열이 뻗치다 & 9.23 & 1.18 \\
\hline 분노 & 부아가 치밀다 & 9.15 & 1.59 \\
\hline 분노 & 이가 갈리다 & 9.14 & 1.33 \\
\hline 분노 & 부아가 나다 & 9.09 & 1.21 \\
\hline 분노 & 분통이 터지다 & 9.08 & 1.44 \\
\hline 분노 & 얼굴이 붉으락푸르락해지다 & 9.08 & 1.35 \\
\hline 분노 & 부아가 오르다 & 9.04 & 1.45 \\
\hline 분노 & 속에서 불(덩어리)이 일다 & 8.97 & 1.55 \\
\hline 분노 & 열을 받다 & 8.96 & 1.32 \\
\hline 분노 & 이를 갈다 & 8.82 & 1.45 \\
\hline 분노 & (입에)게거품을 물다 & 8.78 & 1.81 \\
\hline 분노 & 칼을 갈다 & 8.78 & 1.59 \\
\hline 분노 & 칼을 품다 & 8.76 & 1.56 \\
\hline 분노 & 피가 끓다 & 8.71 & 1.47 \\
\hline 분노 & 복장 뒤집다 & 8.69 & 1.71 \\
\hline 분노 & 속이 뒤집히다 & 8.69 & 1.55 \\
\hline 분노 & 치를 떨다 & 8.66 & 1.75 \\
\hline 분노 & 눈을 까뒤집다 & 8.60 & 1.58 \\
\hline 분노 & 눈에 (칼)날이 서다 & 8.60 & 1.81 \\
\hline 분노 & 눈에 쌍심지를 켜다 & 8.52 & 1.90 \\
\hline 분노 & 거품을 물다 & 8.51 & 2.02 \\
\hline 분노 & 핏대를 올리다 & 8.51 & 1.74 \\
\hline 분노 & 눈에 핏발을 세우다 & 8.48 & 1.84 \\
\hline 분노 & 열이 오르다 & 8.47 & 1.83 \\
\hline 분노 & 피가 용솟음치다 & 8.39 & 1.73 \\
\hline 분노 & 주먹을 떨다 & 8.28 & 2.23 \\
\hline 분노 & 속을 뒤집다 & 8.26 & 1.83 \\
\hline 분노 & 눈에서 불이 나다 & 8.25 & 2.11 \\
\hline 분노 & 뒤통수를 치다 & 8.25 & 1.94 \\
\hline 분노 & 열을 내다 & 8.25 & 1.81 \\
\hline 분노 & 뿔이 나다 & 8.21 & 2.08 \\
\hline 분노 & 핏대를 세우다 & 8.14 & 2.37 \\
\hline 분노 & 악을 쓰다 & 8.14 & 2.02 \\
\hline 분노 & 눈을 부라리다 & 8.12 & 2.34 \\
\hline 분노 & 발등을 찍히다 & 8.10 & 2.05 \\
\hline 분노 & 가슴이 터지다 & 8.06 & 1.78 \\
\hline 분노 & 속이 끓다 & 8.02 & 2.28 \\
\hline
\end{tabular}


[Appendix 1] 각 범주 별 관용어 목록 (Continued)

\begin{tabular}{|c|c|c|c|}
\hline $\begin{array}{l}\text { 감정 } \\
\text { 범주 }\end{array}$ & 관용어 & $\begin{array}{c}\text { 감정강도 } \\
\text { 평균 }\end{array}$ & $\begin{array}{l}\text { 감정강도 } \\
\text { 표준편차 }\end{array}$ \\
\hline 분노 & 속을 끓이다 & 7.97 & 2.09 \\
\hline 분노 & 바람을 피우다 & 7.97 & 2.28 \\
\hline 분노 & 펄펄 뛰다 & 7.89 & 2.23 \\
\hline 분노 & 복장이 터지다 & 7.89 & 2.13 \\
\hline 분노 & 속이 터지다 & 7.88 & 2.05 \\
\hline 분노 & 돈을 날리다 & 7.83 & 2.20 \\
\hline 분노 & 열을 올리다 & 7.82 & 1.91 \\
\hline 분노 & 도끼눈을 뜨다 & 7.76 & 2.05 \\
\hline 분노 & 욕을 먹다 & 7.74 & 2.07 \\
\hline 분노 & 눈을 치뜨다 & 7.74 & 1.99 \\
\hline 분노 & 두 눈을 부릅뜨다 & 7.73 & 2.41 \\
\hline 분노 & 복장이 타다 & 7.63 & 2.01 \\
\hline 분노 & 바가지(를) 쓰다 & 7.62 & 1.96 \\
\hline 분노 & 오만상을 찌푸리다 & 7.62 & 2.27 \\
\hline 분노 & 가슴이 끓어오르다 & 7.60 & 2.05 \\
\hline 분노 & 바가지를 씨우다 & 7.59 & 2.17 \\
\hline 분노 & 눈에 불을 켜다 & 7.55 & 2.43 \\
\hline 분노 & 쑥밭이 되다 & 7.53 & 1.89 \\
\hline 분노 & 기가 막히다 & 7.49 & 2.20 \\
\hline 분노 & 소리치고 싶다 & 7.48 & 2.03 \\
\hline 분노 & 뱃속이 뒤틀리다 & 7.29 & 2.84 \\
\hline 분노 & 주먹을 불끈 쥐다 & 7.23 & 2.28 \\
\hline 분노 & 말이 안 나오다 & 7.22 & 2.60 \\
\hline 분노 & 침을 뱉다 & 7.14 & 2.42 \\
\hline 분노 & 골이 나다. & 7.14 & 2.30 \\
\hline 분노 & 등을 돌리다 & 7.05 & 2.46 \\
\hline 분노 & 기가 차다 & 6.96 & 2.47 \\
\hline 분노 & 인상을 쓰다 & 6.92 & 2.76 \\
\hline 분노 & 바가지를 긁다 & 6.84 & 2.50 \\
\hline 분노 & 바람(을) 맞다 & 6.77 & 2.55 \\
\hline 분노 & 으름장을 놓다 & 6.74 & 2.36 \\
\hline 분노 & 마음에 담다 & 6.57 & 2.62 \\
\hline 분노 & 눈 초리가 차갑다 & 6.52 & 2.41 \\
\hline 분노 & 눈을 흘기다 & 6.31 & 2.36 \\
\hline 분노 & 국물도 없다 & 6.30 & 2.27 \\
\hline 분노 & 귀에 거슬리다 & 6.27 & 2.72 \\
\hline 분노 & 큰 코 다치다 & 6.09 & 2.83 \\
\hline 분노 & 입씨름 하다 & 5.98 & 2.11 \\
\hline 분노 & 골치 아프다 & 5.94 & 2.63 \\
\hline
\end{tabular}

[Appendix 1] 각 범주 별 관용어 목록 (Continued)

\begin{tabular}{|c|c|c|c|}
\hline $\begin{array}{l}\text { 감정 } \\
\text { 범주 }\end{array}$ & 관용어 & $\begin{array}{c}\text { 감정강도 } \\
\text { 평균 }\end{array}$ & $\begin{array}{l}\text { 감정강도 } \\
\text { 표준편차 }\end{array}$ \\
\hline 분노 & 신경을 곤두세우다 & 5.94 & 2.47 \\
\hline 분노 & 담을 쌓다 & 5.88 & 2.37 \\
\hline 분노 & 눈꼴이 시다 & 5.79 & 2.58 \\
\hline 분노 & 골머리를 썩이다 & 5.67 & 2.30 \\
\hline 분노 & 속(이) 타다 & 5.61 & 2.59 \\
\hline 분노 & 속이 좁다 & 5.42 & 2.30 \\
\hline 분노 & 눈 밖에 나다 & 5.41 & 2.63 \\
\hline 분노 & 점수가 짜다 & 5.32 & 2.41 \\
\hline 분노 & 눈밖에 벗어나다 & 5.25 & 2.64 \\
\hline 분노 & 배부른 소리를 하다 & 5.03 & 2.61 \\
\hline 분노 & 입을 내밀다 & 4.67 & 2.27 \\
\hline 분노 & 입을 삐죽이다 & 4.33 & 2.20 \\
\hline 슬픔 & 가슴이 무너지다 & 9.47 & 1.01 \\
\hline 슬픔 & 가슴이 찢어지다(찢기다) & 9.41 & 1.26 \\
\hline 슬픔 & 목 놓아 울다 & 9.37 & 1.21 \\
\hline 슬픔 & 억장이 무너지다 & 9.28 & 1.44 \\
\hline 슬픔 & 하늘이 무너지다 & 9.26 & 1.22 \\
\hline 슬픔 & 가슴에 대못을 박다 & 9.24 & 1.43 \\
\hline 슬픔 & 가슴을 도려내다 & 9.12 & 1.73 \\
\hline 슬픔 & 가슴이 미어지다 & 9.09 & 1.47 \\
\hline 슬픔 & 눈물이 앞을 가리다 & 9.04 & 1.51 \\
\hline 슬픔 & 피눈물(이) 나다 & 8.94 & 1.92 \\
\hline 슬픔 & 숨을 거두다 & 8.91 & 1.95 \\
\hline 슬픔 & 가슴에 멍이 들다 & 8.88 & 1.48 \\
\hline 슬픔 & 가슴에 피멍이 들다 & 8.83 & 1.53 \\
\hline 슬픔 & 눈물을 삼키다 & 8.82 & 1.71 \\
\hline 슬픔 & 가슴에 구멍이 똟리다 & 8.80 & 1.75 \\
\hline 슬픔 & 눈시울을 적시다 & 8.79 & 1.40 \\
\hline 슬픔 & 가슴이 아프다 & 8.78 & 1.92 \\
\hline 슬픔 & 눈에서 피눈물이 나다 & 8.75 & 2.04 \\
\hline 슬픔 & 목이 메(이)다 & 8.75 & 1.55 \\
\hline 슬픔 & 가슴을 저미다 & 8.64 & 1.72 \\
\hline 슬픔 & 눈시울이 시큰해지다 & 8.62 & 1.62 \\
\hline 슬픔 & 심금을 울리다 & 8.55 & 1.88 \\
\hline 슬픔 & 꿈을 접다 & 8.52 & 1.75 \\
\hline 슬픔 & 마음이 다치다 & 8.51 & 1.76 \\
\hline 슬픔 & 가슴이 저리다 & 8.48 & 1.93 \\
\hline 슬픔 & 눈시울을 붉히다 & 8.44 & 1.71 \\
\hline 슬픔 & 눈물이 핑 돌다 & 8.43 & 1.91 \\
\hline
\end{tabular}


[Appendix 1] 각 범주 별 관용어 목록 (Continued)

\begin{tabular}{|c|c|c|c|}
\hline 감정 & 관용어 & $\begin{array}{c}\text { 감정강도 } \\
\text { 평균 }\end{array}$ & $\begin{array}{l}\text { 감정강도 } \\
\text { 표준편차 }\end{array}$ \\
\hline 슬픔 & 가슴이 뭉클하다 & 8.43 & 8.88 \\
\hline 슬픔 & 가슴이 쓰(라)리다 & 8.41 & 1.88 \\
\hline 슬픔 & 가슴이 저미다 & 8.40 & 1.81 \\
\hline 슬픔 & 가슴에/로 파고들다 & 8.37 & 2.14 \\
\hline 슬픔 & 땅을 치다 & 8.35 & 1.91 \\
\hline 슬픔 & 눈시울이 뜨거워지다 & 8.31 & 1.98 \\
\hline 슬픔 & 가슴이 내려앉다 & 8.23 & 2.04 \\
\hline 슬픔 & 콧날이 찡하다 & 8.14 & 1.97 \\
\hline 슬픔 & 콧날이 시큰하다(해지다) & 8.12 & 1.89 \\
\hline 슬픔 & 코끝이 찡하다 & 8.10 & 1.92 \\
\hline 슬픔 & 애가 끓다 & 8.08 & 1.99 \\
\hline 슬픔 & 목이 잠기다 & 7.98 & 2.02 \\
\hline 슬픔 & 가슴이 찡하다 & 7.94 & 2.20 \\
\hline 슬픔 & 속이 상하다 & 7.94 & 1.98 \\
\hline 슬픔 & 가슴을 적시다 & 7.94 & 2.15 \\
\hline 슬픔 & 가슴을 짓누르다 & 7.92 & 2.04 \\
\hline 슬픔 & 물거품이 되다 & 7.90 & 2.22 \\
\hline 슬픔 & 눈시울이 맵다 & 7.90 & 2.18 \\
\hline 슬픔 & 하늘이 캄캄하다 & 7.88 & 2.32 \\
\hline 슬픔 & 가슴을 찌르다 & 7.86 & 1.91 \\
\hline 슬픔 & 속상하다 & 7.80 & 1.94 \\
\hline 슬픔 & 콧등이 시큰하다 & 7.76 & 2.12 \\
\hline 슬픔 & 눈이 벌겅다 & 7.71 & 2.23 \\
\hline 슬픔 & 가슴이 타다 & 7.62 & 1.95 \\
\hline 슬픔 & 가슴을 울리다 & 7.53 & 2.71 \\
\hline 슬픔 & 마음이 상하다 & 7.48 & 2.47 \\
\hline 슬픔 & 가슴이 막히다 & 7.43 & 2.30 \\
\hline 슬픔 & 미역국을 먹다 & 7.33 & 2.22 \\
\hline 슬픔 & 애(가) 타다 & 7.19 & 2.34 \\
\hline 슬픔 & 마음이 비다 & 7.15 & 2.34 \\
\hline 슬픔 & 어깨가 처지다 & 7.09 & 2.35 \\
\hline 슬픔 & 마음이 무겁다 & 7.06 & 2.16 \\
\hline 슬픔 & 밥맛이 없다 & 6.95 & 2.14 \\
\hline 슬픔 & 한잔 마시다 & 6.91 & 2.48 \\
\hline 슬픔 & 꿈도 못 꾸다 & 6.88 & 2.35 \\
\hline 슬픔 & 고개를 떨구다 & 6.86 & 1.99 \\
\hline 슬픔 & 귓전을 울리다 & 6.86 & 2.56 \\
\hline 슬픔 & 한숨만 나온다(짓다) & 6.85 & 2.28 \\
\hline 슬픔 & 가슴이 답답하다 & 6.82 & 2.41 \\
\hline
\end{tabular}

[Appendix 1] 각 범주 별 관용어 목록 (Continued)

\begin{tabular}{|c|c|c|c|}
\hline $\begin{array}{l}\text { 감정 } \\
\text { 범주 }\end{array}$ & 관용어 & $\begin{array}{c}\text { 감정강도 } \\
\text { 평균 }\end{array}$ & $\begin{array}{l}\text { 감정강도 } \\
\text { 표준편차 }\end{array}$ \\
\hline 슬픔 & 가슴이 무겁다 & 6.75 & 2.68 \\
\hline 슬픔 & 속을 태우다 & 6.73 & 2.28 \\
\hline 슬픔 & 애간장이 녹다 & 6.72 & 2.61 \\
\hline 슬픔 & 맥이 빠지다 & 6.68 & 2.44 \\
\hline 슬픔 & 얼굴이 상하다 & 6.67 & 2.34 \\
\hline 슬픔 & 속(을) 썩이다 & 6.67 & 2.33 \\
\hline 슬픔 & 땅에 떨어지다 & 6.62 & 2.10 \\
\hline 슬픔 & 발걸음이 무겁다 & 6.58 & 2.20 \\
\hline 슬픔 & 가슴에 담아두다 & 6.57 & 2.40 \\
\hline 슬픔 & 애를 태우다 & 6.50 & 2.60 \\
\hline 슬픔 & 무릎을 꼻다 & 6.49 & 2.41 \\
\hline 슬픔 & 금이 가다 & 6.49 & 2.36 \\
\hline 슬픔 & 고개를 숙이다 & 6.38 & 2.17 \\
\hline 슬픔 & 풀이 꺾이다 & 6.24 & 2.51 \\
\hline 슬픔 & 주머니가 가볍다 & 6.20 & 2.27 \\
\hline 슬픔 & 풀이 죽다 & 6.17 & 2.35 \\
\hline 슬픔 & 어깨가 늘어지다 & 6.10 & 2.74 \\
\hline 슬픔 & 눈(앞)에 아른거리다 & 6.06 & 2.20 \\
\hline 슬픔 & 애를 끓다 & 6.03 & 3.01 \\
\hline 슬픔 & 머리를 숙이다 & 5.97 & 2.86 \\
\hline 슬픔 & 눈에 아른거리다 & 5.97 & 2.11 \\
\hline 슬픔 & 기가 죽다 & 5.95 & 2.21 \\
\hline 슬픔 & 입맛이 씁쓸하다 & 5.87 & 2.33 \\
\hline 슬픔 & 입맛이 쓰다 & 5.78 & 2.35 \\
\hline 슬픔 & 한풀 꺾이다 & 5.76 & 2.52 \\
\hline 슬픔 & 엎질러진 물 & 5.59 & 2.41 \\
\hline 슬픔 & 눈에 밟히다 & 5.59 & 2.47 \\
\hline 슬픔 & 눈(앞)에 밟히다 & 5.42 & 2.32 \\
\hline 슬픔 & 기가 꺾이다 & 5.40 & 2.83 \\
\hline 슬픔 & 마음에 걸리다 & 5.00 & 1.90 \\
\hline 통증 & 뼈를 깎는 듯한 & 8.94 & 1.82 \\
\hline 통증 & 살을 도려내다 & 8.68 & 1.75 \\
\hline 통증 & 허리가 끓어지다 & 8.60 & 1.94 \\
\hline 통증 & 허리가 부러지다 & 8.47 & 1.89 \\
\hline 통증 & 배가 아프다 & 7.95 & 2.34 \\
\hline 통증 & 살을 깎다 & 7.83 & 2.59 \\
\hline 통증 & 쥐가 나다 & 7.77 & 2.32 \\
\hline 통증 & 열이 나다 & 7.56 & 2.32 \\
\hline 통증 & 머리가 무겁다 & 7.38 & 2.36 \\
\hline
\end{tabular}


[Appendix 1] 각 범주 별 관용어 목록 (Continued)

\begin{tabular}{|c|c|c|c|}
\hline $\begin{array}{l}\text { 감정 } \\
\text { 범주 }\end{array}$ & 관용어 & $\begin{array}{c}\text { 감정강도 } \\
\text { 평균 }\end{array}$ & $\begin{array}{l}\text { 감정강도 } \\
\text { 표준편차 }\end{array}$ \\
\hline 통증 & 뼈가 저리다 & 7.30 & 2.37 \\
\hline 통증 & 하늘이 노랗다 & 7.13 & 2.66 \\
\hline 통증 & 숨이 막히다 & 7.09 & 2.39 \\
\hline 통증 & 속이 쓰리다 & 6.97 & 2.54 \\
\hline 통증 & 귀가 아프다 & 6.84 & 2.55 \\
\hline 통증 & 몸이 축나다 & 6.62 & 2.38 \\
\hline 통증 & 몸이 무겁다 & 6.57 & 2.77 \\
\hline 통증 & 골머리를 않다 & 6.47 & 2.23 \\
\hline 통증 & 숨이 가쁘다 & 6.40 & 2.58 \\
\hline 통증 & 파김치가 되다 & 6.05 & 2.89 \\
\hline 통증 & 가슴이 울렁거리다 & 5.76 & 2.33 \\
\hline 통증 & 가슴이 찔리다 & 5.72 & 2.67 \\
\hline 통증 & 애(를) 먹다 & 5.08 & 2.24 \\
\hline 통증 & 입이 아프다 & 5.04 & 2.18 \\
\hline 혐오 & 구역질이 나다 & 9.22 & 1.53 \\
\hline 혐오 & 구역질을 느끼다 & 8.80 & 1.96 \\
\hline 혐오 & 얼굴을 찌푸리다 & 7.61 & 2.30 \\
\hline 혐오 & 밥맛이 떨어지다 & 7.53 & 2.21 \\
\hline 혐오 & 눈도 거들떠보지 않다 & 7.46 & 2.66 \\
\hline 혐오 & 눈에 가시 & 7.41 & 2.23 \\
\hline 혐오 & 눈꼴이 사납다 & 7.30 & 2.17 \\
\hline 혐오 & 눈살을 찌푸리다 & 7.16 & 2.32 \\
\hline 혐오 & 눈살을 찡그리다 & 7.00 & 2.48 \\
\hline 혐오 & 속이 느글거리다 & 6.95 & 2.55 \\
\hline 혐오 & 이맛살을 찌푸리다 & 6.92 & 2.44 \\
\hline 혐오 & 뒤가 구리다 & 6.85 & 2.32 \\
\hline 혐오 & 낮이 두껍다 & 6.16 & 2.48 \\
\hline 혐오 & 혀를 차다 & 5.83 & 2.83 \\
\hline 혐오 & 콧방귀를 끼다 & 5.33 & 2.43 \\
\hline 혐오 & 고개를 돌리다 & 5.16 & 2.54 \\
\hline 혐오 & 사람이 짜다 & 5.08 & 2.32 \\
\hline 지루 & 파리 날리다 & 8.83 & 1.63 \\
\hline 지루 & 틀에 박히다 & 8.46 & 2.13 \\
\hline 지루 & 눈에 안 들어오다 & 8.31 & 2.01 \\
\hline 지루 & 귀에 못이 박히다 & 8.30 & 1.76 \\
\hline 지루 & 눈을 돌리다 & 8.07 & 2.15 \\
\hline 흥미 & 눈이 빛나다 & 9.19 & 1.27 \\
\hline 흥미 & 심혈을 기울이다 & 8.75 & 1.82 \\
\hline 흥미 & 한눈에 반하다 & 8.74 & 1.83 \\
\hline
\end{tabular}

[Appendix 1] 각 범주 별 관용어 목록 (Continued)

\begin{tabular}{|c|c|c|c|}
\hline $\begin{array}{l}\text { 감정 } \\
\text { 범주 }\end{array}$ & 관용어 & $\begin{array}{c}\text { 감정강도 } \\
\text { 평균 }\end{array}$ & $\begin{array}{l}\text { 감정강도 } \\
\text { 표준편차 }\end{array}$ \\
\hline 흥미 & 귀가 솔깃하다 & 8.52 & 1.66 \\
\hline 흥미 & 마음이 끌리다 & 8.51 & 1.64 \\
\hline 흥미 & 눈(길)을 끌다 & 8.48 & 1.57 \\
\hline 흥미 & 이목을 끌다 & 8.35 & 1.64 \\
\hline 흥미 & 가슴을 뒤흔들다 & 8.23 & 1.91 \\
\hline 흥미 & 눈이 돌아가다 & 8.21 & 2.23 \\
\hline 흥미 & 귀(를) 기울이다 & 8.20 & 1.97 \\
\hline 흥미 & 눈길을 모으다 & 8.12 & 1.79 \\
\hline 흥미 & 눈을 번뜩이다 & 8.08 & 1.79 \\
\hline 흥미 & 넋이 팔리다 & 8.07 & 2.02 \\
\hline 흥미 & 군침이 돌다 & 8.03 & 1.87 \\
\hline 흥미 & 마음은 굴뚝같다 & 7.97 & 1.89 \\
\hline 흥미 & 마음에 두다 & 7.74 & 2.09 \\
\hline 흥미 & 눈(길)을 주다 & 7.71 & 2.00 \\
\hline 흥미 & 손이 가다 & 7.70 & 2.08 \\
\hline 흥미 & 눈길이 미치다 & 7.61 & 1.98 \\
\hline 흥미 & 정신이 팔리다 & 7.55 & 1.87 \\
\hline 흥미 & 눈에 들다 & 7.52 & 2.15 \\
\hline 흥미 & 눈이 빠지게 & 7.52 & 2.19 \\
\hline 흥미 & 전기가 통하다 & 7.49 & 1.92 \\
\hline 흥미 & 마음을 붙이다 & 7.43 & 2.08 \\
\hline 흥미 & 침을 흘리다 & 7.42 & 2.31 \\
\hline 흥미 & 군침을 흘리다 & 7.41 & 1.72 \\
\hline 흥미 & 가슴에 (와) 닿다 & 7.32 & 2.07 \\
\hline 흥미 & 마음이 굴뚝같다 & 7.32 & 2.11 \\
\hline 흥미 & 마음을 먹다 & 7.24 & 2.05 \\
\hline 흥미 & 발 벗고 나서다 & 7.16 & 2.29 \\
\hline 흥미 & 군침을 삼키다 & 7.10 & 2.29 \\
\hline 흥미 & 눈에 어리다 & 7.06 & 1.88 \\
\hline 흥미 & 귀에 맴돌다 & 6.97 & 2.05 \\
\hline 흥미 & 입맛이 당기다 & 6.90 & 2.10 \\
\hline 흥미 & 귓가에 맴돌다 & 6.68 & 2.30 \\
\hline 흥미 & 머리에 맴돌다 & 6.55 & 2.03 \\
\hline 흥미 & 마음을 쓰다 & 6.44 & 2.26 \\
\hline 흥미 & 귓전에 아른거리다 & 6.35 & 2.59 \\
\hline 흥미 & 낯(이) 익다 & 5.88 & 2.34 \\
\hline 흥미 & 마음이 쓰이다 & 5.83 & 2.53 \\
\hline
\end{tabular}


[Appendix 2] 다중 사용 관용어 (일부)

\begin{tabular}{l|c|c|c}
\hline \multicolumn{1}{|c|}{ 관용어 } & $\begin{array}{c}\text { 1차 감정 } \\
\text { 범주 }\end{array}$ & $\begin{array}{c}\text { 2차 감정 } \\
\text { 범주 }\end{array}$ & $\begin{array}{c}\text { 3차 감정 } \\
\text { 범주 }\end{array}$ \\
\hline 닭살이 돋다 & 공포 & 혐오 & 놀람 \\
\hline 눈앞이 캄캄(깜깜)하다 & 공포 & 슬픔 & \\
\hline 애지중지하다 & 기쁨 & 흥미 & \\
\hline 눈에 차다 & 기쁨 & 흥미 & \\
\hline 눈이 맞다 & 기쁨 & 흥미 & \\
\hline 가슴이 두근거리다 & 기쁨 & 흥미 & \\
\hline 가슴이 뜨거워지다(뜨겁다) & 기쁨 & 흥미 & \\
\hline 심장이 뛰다 & 기쁨 & 놀람 & \\
\hline 가슴이 떨리다 & 기쁨 & 공포 & \\
\hline 가슴이 덜컥(덜컹) 내려앉다 & 놀람 & 슬픔 & 공포 \\
\hline 가슴이 철렁 내려앉다 & 놀람 & 슬픔 & 공포 \\
\hline 무릎을 치다 & 놀람 & 기쁨 & 흥미 \\
\hline 말문이 막히다 & 놀람 & 분노 & \\
\hline 입이 붙어 떨어지지 않다 & 놀람 & 공포 & \\
\hline 눈꼴이 시다 & 분노 & 혐오 & \\
\hline 복장이 타다 & 분노 & 슬픔 & \\
\hline 눈초리가 차갑다 & 분노 & 혐오 & 공포 \\
\hline 가슴이 터지다 & 분노 & 슬픔 & 기쁨 \\
\hline 속을 끓이다 & 분노 & 슬픔 & \\
\hline 땅을 치다 & 슬픔 & 분노 & \\
\hline 하늘이 캄캄하다 & 슬픔 & 공포 & \\
\hline 하늘이 노랗다 & 통증 & 슬픔 & 공포 \\
\hline 낯이 두껍다 & 혐오 & 분노 & \\
\hline 한눈에 반하다 & 흥미 & 기쁨 & \\
\hline 가슴에 와 닿다 & 흥미 & 기쁨 & \\
\hline 가슴을 뒤흔들다 & 흥미 & 슬픔 & 기쁨 \\
\hline
\end{tabular}

\section{Author listings}

Ji-Eun Park: jieun711@cnu.ac.kr

Highest degree: MS, Department of Psychology, Chungnam National University

Position title: Researcher, Department of Psychology, Chungnam National University

Areas of interest: HCI, Human Emotion and Cognition

Sunju Sohn: ssohn124@cju.ac.kr

Highest degree: $\mathrm{PhD}$, School of Social Work, University of Texas Austin Position title: Assistant Professor, Department of Social Welfare, Cheongju University

Areas of interest: Bio-psycho-social Alcoholism, Cultural Competence

Jin-Hun Sohn: jhsohn@cnu.ac.kr

Highest degree: $\mathrm{PhD}$, Department of Psychology, Korea University Position title: Professor, Department of Psychology, Chungnam National University

Areas of interest: HCI, Human Emotion and Cognition

Date Received : 2012-04-02

Date Revised :2012-07-30

Date Accepted : 2012-08-06 